\title{
Comparative study of the tourist destinations of La Barrita and Barra de Potosí, Gro., Mexico
}

\section{Estudio comparativo de los destinos turísticos de La Barrita y Barra de Potosí, Gro., México}

URUEÑA-BARRAGÁN, Carlos Minisak, BRAVO-GONZÁLEZ, José Guillermo, LÓPEZ-NÚÑEZ, Miriam Araceli and GALEANA-ROSALES, Montserrat

Universidad Tecnológica de la Costa Grande de Guerrero, Carretera Nacional Acapulco-Zihuatanejo Km. 201. Ejido "El Cocotero, Petatlán, Guerrero, C.P. 40830

ID $1^{\text {st }}$ Author: Carlos Minisak, Urueña-Barragán / ORC ID: 0000-0001-9476-6469, Researcher ID Thomson: Q-96742018, CVU CONACYT ID: 596252

ID $1^{\text {st }}$ Coauthor: José Guillermo, Bravo-González / ORC ID: 0000-0001-5910-6633, Researcher ID Thomson: Q-97492018, CVU CONACYT ID: 942156

ID $2^{\text {nd }}$ Coauthor: Miriam Araceli, López-Núñez / ORC ID: 0000-0001-9570-2088, Researcher ID Thomson: Q-9816-2018, CVU CONACYT ID: 653444

ID $3^{\text {rd }}$ Coauthor: Montserrat, Galeana-Rosales / ORC ID: 0000-0002-0667-7771, Researcher ID Thomson: Q-9668-2018, CVU CONACYT ID: 573958

DOI: $10.35429 / \mathrm{JM} \cdot 2019.5 .3 .24 .29$

Received October 10, 2019; Accepted December 20, 2019

\section{Abstract}

Guerrero is a state with tourist infrastructure. But there are still certain coastal areas in Guerrero that require government attention and allow the development of its inhabitants. That is the case of Playa La Barrita, and on the other hand Barra de Potosí. The lack of development of the tourist destinations of these places, which despite the years, still do not reach progress, which allows to raise the quality of life of its inhabitants. The object of study of the present investigation is to know the causes that have not allowed to reach their maximum potential of the tourist destinations of La Barrita and Barra de Potosí. In this sense, the research is descriptive, and was carried out through the application of a $100 \%$ instrument from a universe of 55 establishments, with a maximum acceptable error of $5 \%$ and a 95\% confidence level, which determined that between the reasons why both tourist destinations have not reached their potential, are the lack of services (drinking water, drainage, internet access, solid waste management), and lack of government investment, as well as the approach to The different banking institutions. It is important to approach government institutions, with the inhabitants, businessmen and other providers of tourism services that allow to seek alternatives to improve the supply of services, and in turn reduce ecological damage in the future.

Development, Services, Investment
Resumen

Guerrero es un estado con infraestructura turística. Pero aún quedan ciertas zonas costeras guerrerenses, que requieren atención del gobierno, y permitan el desarrollo de sus habitantes. Ese es el caso de Playa La Barrita, y por otro lado Barra de Potosí. La falta de desarrollo de los destinos turísticos de dichos lugares, los cuales a pesar de los años, siguen sin alcanzar un progreso, que permita elevar la calidad de vida de sus habitantes. El objeto de estudio de la presente investigación es conocer las causas que no han permitido alcanzar su máximo potencial de los destinos turísticos de La Barrita y Barra de Potosí. En este sentido la investigación es descriptiva, y se realizó a través de la aplicación de un instrumento al $100 \%$ de un universo de 55 establecimientos, con un error máximo aceptable de $5 \%$ y un nivel de confianza al $95 \%$, que determinaron que entre las causas por las que ambos destinos turísticos no han alcanzado a detonar su potencial, se encuentran la falta de servicios (agua potable, drenaje, acceso a internet, manejo de los residuos sólidos), y falta de inversión gubernamental, así como el acercamiento a las diferentes instituciones de la banca. Es importante el acercamiento de las instituciones de gobierno, con los habitantes, empresarios y demás prestadores de servicios turísticos que permitan buscar alternativas para mejorar la oferta de servicios, y a su vez reducir el daño ecológico en un futuro.

Desarrollo, Servicios, Inversión

Citation: URUEÑA-BARRAGÁN, Carlos Minisak, BRAVO-GONZÁLEZ, José Guillermo, LÓPEZ-NÚÑEZ, Miriam Araceli and GALEANA-ROSALES, Montserrat. Comparative study of the tourist destinations of La Barrita and Barra de Potosí, Gro., Mexico. Journal-Microeconomics. 2019. 3-5: 24-29

\footnotetext{
* Correspondence to Author (email: c_uruena@utcgg.edu.mx)

$\dagger$ Researcher contributing first author.
} 


\section{Introduction}

La Barrita Beach, is located in the municipality of Petatlán, Guerrero, being a passing destination where people who travel by road to Ixtapa or Zihuatanejo, enjoy an extremely exclusive beach for those who come to it, where they enjoy rich dishes prepared from the sea with seafood and fish, at very affordable prices.

On the other hand Barra de Potosí, is located in the municipality of Petatlán, Guerrero, being a small community by the sea that is located at the end of Playa Blanca, and 35 minutes by car from the town of Zihuatanejo, in the municipality of Zihuatanejo from Azueta, Guerrero and 34 minutes from Petatlán, in the Municipality of Petatlán, Guerrero, where vacationers can taste delicious food at very affordable prices.

The fact is that both destinations since the mid-twentieth century, begin to provide the food preparation service, as a complementary form of their main activity that was fishing, and even today many of the dishes that are offered are products of fishing

Since there was no development plan on the part of the municipal government, and since the lands were ejido, the settlers were organizing, and they were building their boughs, and today we can observe how most of them have not changed since the beginning, with some exceptions.

In this sense, the municipal government, not responding to the primary needs of the inhabitants of these population centers, proves that they do not have basic services, drinking water and sanitary sewer, only the garbage collection service is provided.

\section{Problem Statement}

The lack of growth of the tourist destinations of La Barrita and Barra de Potosí, which despite the years, still do not reach a development, which allows to raise the quality of life of its inhabitants.

Having all that potential to grow, why have the tourist destinations of La Barrita and Barra de Potosí not triggered their economic potential?

\section{Objective}

Analyze the reasons why both tourist destinations have not been able to achieve development, to look for alternatives and support from the three levels of government.

\section{Theoretical framework}

To begin with, Gómez (1996) refers to the objectives of a social organization, which are the aims or goals that it intends to achieve through collective effort.

As Piovani, JI, Nora Krawczyk, N. (2017) mentions in the case of social sciences, the impossibility of accepting the assumptions of traditional conceptions of science, or their rejection, has given rise to a series of perspectives in the that the comparison is used for ideographic or interpretive purposes. The emphasis then falls on the objects of comparison itself, and not so much on the properties.

On the other hand, for Sartori (1984), the comparative method aims at the search for similarities and dissimilarities. Since the comparison is based on the homogeneity criterion.

Also Porter (1997) mentions that the sources of cost advantages are varied and depend on the structure of the industrial sector, and should achieve proximity in the bases of differentiation in relation to its competitors.

In another order Góngora (2008), taking into account the findings of Hofstede (1999), considers interdependence or diversity, which highlights the importance of mutual influence between the culture of organizations and contextual culture. This perspective basically states that organizations are not islands and that, to understand their culture, the culture of the context in which they act must be taken into account.

By the way according to the census of INEGI (2013) 42004 economic units are dedicated to private non-financial services in Guerrero, which represents $31 \%$ of the total establishments of the private and parastatal sector in the entity. 


\section{Methodology}

The research is descriptive, to know the reasons why both tourist destinations have not reached to detonate their potential, and that allow us to propose alternatives for maximum development.

First, the instrument was designed to know the information according to the previously established criteria. With the main purpose of establishing the differences between the two destinations that are tried to compare, to know the causes that have not allowed the development of the tourist destinations, of $\mathrm{La}$ Barrita and Barra de Potosí, considering their natural advantages, and development potential.

Afterwards, they went to the regulations offices of the Municipality of Petatlán, in the State of Guerrero, to request a census of the registered businesses, but they could not grant us the required information, since they did not have the information, perhaps lost in the change of administration.

In this sense, in order to carry out the project, it was necessary to move to the destinations, to make a business count, once the required information was obtained. A $100 \%$ instrument from a universe of 55 establishments was applied, with a maximum acceptable error of $5 \%$ and a $95 \%$ confidence level,

Once the number of establishments to be surveyed was determined, the Bar was first visited, for the application of the instrument, taking an average of 20 minutes, in its application, to each of the respondents, with a total of 15 businesses.

Afterwards, we went to the Potosí Bar, for the application of the instrument, taking an average of 25 minutes, in its application, to each of the respondents, being a total of 40 businesses.

In order to compare the differences in terms of transfer time, the population of Zihuatanejo de Azueta was considered, due to the proximity to the destination and its impact on the Potosí Bar, as well as the Petatlán Population, so the transfer to the destinations in the three chosen means of transport, to know the time to reach the destinations under study, it is important to mention that there are some applications that can do this process, but they cannot calculate the time in public transport because there is no schedule defined, in addition to having to transfer and the conditions are not ideal, so it was necessary to move in the three media.

\section{Results}

1. The differences in terms of the basic services provided to the client that goes to the destinations, outside of food and beverages, that customers today look for, such as internet access, electric power to recharge electrical devices (mobile phones, equipment of computing, cameras, etc.). and fixed telephony.

\begin{tabular}{|l|l|l|}
\hline \multicolumn{1}{|c|}{$\begin{array}{l}\text { Differences } \\
\text { regarding: }\end{array}$} & $\begin{array}{c}\text { Services provided by } \\
\text { the destination of } \\
\text { Barra de Potosí }\end{array}$ & $\begin{array}{c}\text { Services provided by } \\
\text { the destination of La } \\
\text { Barrita }\end{array}$ \\
\hline Internet & $\mathrm{Si}$ & $\mathrm{No}$ \\
\hline $\begin{array}{l}\text { Fixed } \\
\text { telephony }\end{array}$ & $\mathrm{Si}$ & No \\
\hline Electric power & $\mathrm{No}$ & No \\
\hline
\end{tabular}

Table 1 Internet, electricity and landline services

As Table 1 shows, in the Potosí Bar, the internet access and landline service is provided to the attendees, at a cost for the service, making a clarification in this regard that not all facilities are provided, not so in the bar where there is only one booth that provides fixed telephone service, with respect to electricity in either of the two destinations provides it.

2. Another factor to compare the proximity with the destination and its impact of the clients that come from The population of Zihuatanejo de Azueta, the Potosí Bar, as well as the clients that come from the Population of Petatlán To compare the place of origin of the client that go to the destinations.

\begin{tabular}{|l|ll|}
\hline $\begin{array}{c}\text { Differences } \\
\text { regarding: }\end{array}$ & $\begin{array}{c}\text { National and } \\
\text { international } \\
\text { tourism that goes } \\
\text { from Zihuatanejo to } \\
\text { the Barra de Potosí }\end{array}$ & $\begin{array}{c}\text { National and } \\
\text { international } \\
\text { tourism that goes } \\
\text { from Petatlán to } \\
\text { Barra de Potosí }\end{array}$ \\
\hline Nationals & $70 \%$ & $99 \%$ \\
\hline International & $30 \%$ & $1 \%$ \\
\hline
\end{tabular}

Table 2 Potosí bar

According to table 2, the impact of the proximity of Zihuatanejo with the destination of Barra de Potosí, being a tourist port, allows the mixture of national and international tourism to go to it, and to a lesser extent towards the destination of the Barrita, where it is more than national and local tourism.

URUEÑA-BARRAGÁN, Carlos Minisak, BRAVO-GONZÁLEZ, José Guillermo, LÓPEZ-NÚÑEZ, Miriam Araceli and GALEANAROSALES, Montserrat Comparative study of the tourist destinations of La Barrita and Barra de Potosí, Gro., Mexico. Journal-Microeconomics. 2019 
3. Also to compare the proximity with the destination and its impact of the clients that come from The population of Zihuatanejo de Azueta, the Barrita, as well as the clients that come from the Population of Petatlán To compare the place of origin of the client that comes to the destinies.

\begin{tabular}{|l|l|l|}
\hline $\begin{array}{c}\text { Differences } \\
\text { regarding: }\end{array}$ & $\begin{array}{c}\text { National and } \\
\text { international tourism } \\
\text { that goes from Petatlán } \\
\text { to Barra de Potosí }\end{array}$ & $\begin{array}{c}\text { National and } \\
\text { international tourism } \\
\text { that goes from } \\
\text { Petatlán to La Barrita }\end{array}$ \\
\hline Nationals & $99 \%$ & $99 \%$ \\
\hline International & $1 \%$ & $1 \%$ \\
\hline
\end{tabular}

Table 3 The Bar

According to table 3, the impact of the proximity of Petatlán, with the destination of La Barrita, being an agricultural, livestock and religious tourism population, so that national and local tourism is going to both destinations, and to a lesser extent international tourism.

4. With respect to the transport selected to carry out the transfer, the differences in travel time, according to the transport used to the destinations, the following means of transport.

\begin{tabular}{|c|c|c|c|c|}
\hline $\begin{array}{l}\text { Differences } \\
\text { regarding: }\end{array}$ & $\begin{array}{r}\text { Easy access } \\
\text { from } \\
\text { Zihuatanejo to } \\
\text { the Barra de } \\
\text { Potosí }\end{array}$ & $\begin{array}{r}\text { Easy access } \\
\text { from } \\
\text { Zihuatanejo to } \\
\text { La Barrita }\end{array}$ & $\begin{array}{r}\text { Easy } \\
\text { access } \\
\text { from } \\
\text { Petatlán } \\
\text { to the } \\
\text { Barra de } \\
\text { Potosí }\end{array}$ & $\begin{array}{r}\text { Easy } \\
\text { access } \\
\text { from } \\
\text { Petatlán } \\
\text { to La } \\
\text { Barrita }\end{array}$ \\
\hline $\begin{array}{l}\text { Transfer in } \\
\text { own vehicle }\end{array}$ & 35 minutes & 56 minutes & $\begin{array}{l}34 \\
\text { minutes }\end{array}$ & $\begin{array}{l}19 \\
\text { minutes }\end{array}$ \\
\hline $\begin{array}{l}\text { Public } \\
\text { transport } \\
\text { transfer }\end{array}$ & 1:12 Hrs & 1:40 Hrs. & 1:15 Hrs. & $\begin{array}{l}40 \\
\text { minutes }\end{array}$ \\
\hline Bike transfer & 1:24 Hrs. & 2:54 Hrs. & 1:28 Hrs. & 1:17 Hrs. \\
\hline
\end{tabular}

Table 4 Transfer time

According to the data shown in Table 4, the travel time of both Zihuatanejo de Azueta, and Petatlán to Barra de Potosí, is not significant, but from Zihuatanejo to La Barrita, it is really significant, hence the transfer of the inhabitants of Petatlán is more frequent.

5. On the other hand it is important to compare the differences in public services that are provided by the government that impact on the quality provided to the client, and that in the future will cause an impact on both destinations.

\begin{tabular}{|l|l|l|}
\hline \multicolumn{1}{|c|}{$\begin{array}{c}\text { Differences } \\
\text { regarding: }\end{array}$} & \multicolumn{1}{c|}{$\begin{array}{c}\text { Services provided by } \\
\text { the destination of } \\
\text { Barra de Potosí }\end{array}$} & $\begin{array}{c}\text { Services provided by } \\
\text { the destination of La } \\
\text { Barrita }\end{array}$ \\
\hline Drinking water & $\mathrm{No}$ & $\mathrm{No}$ \\
\hline $\begin{array}{l}\text { Ferris wheel } \\
\text { water }\end{array}$ & $\mathrm{Si}$ & $\mathrm{Si}$ \\
\hline Sewer system & $\mathrm{No}$ & $\mathrm{No}$ \\
\hline Septic tank & $\mathrm{Si}$ & $\mathrm{Si}$ \\
\hline $\begin{array}{l}\text { Garbage } \\
\text { collection }\end{array}$ & $\mathrm{Si}$ & $\mathrm{Si}$ \\
\hline
\end{tabular}

Table 5 Public services

According to the data shown in table 5, there is no supply of drinking water, sanitary sewer and there is only the garbage collection service by the municipal government, in the Barra de Potosí, and in La Barrita, this has caused That the population and the service providers, look for alternatives to this problem, which has consisted of making ferris wheels and artisanal wells for water supply, with respect to drainage they have made septic tanks.

Septic tanks have the problem of how we live in a seismic zone, can cause fractures to the construction causing rupture of the walls and that there are leaks of the debris and contaminate the chiatic mantles. On the other hand, when washing utensils and kitchen waxes, the water that is the product of cleaning, one part is poured into the sea and another is used to irrigate the access, which produces unpleasant odors, since doing so in septic tanks would damage the bacteria that they make the process of waste disposal, so with this long-term daily action it will cause irreparable ecological damage.

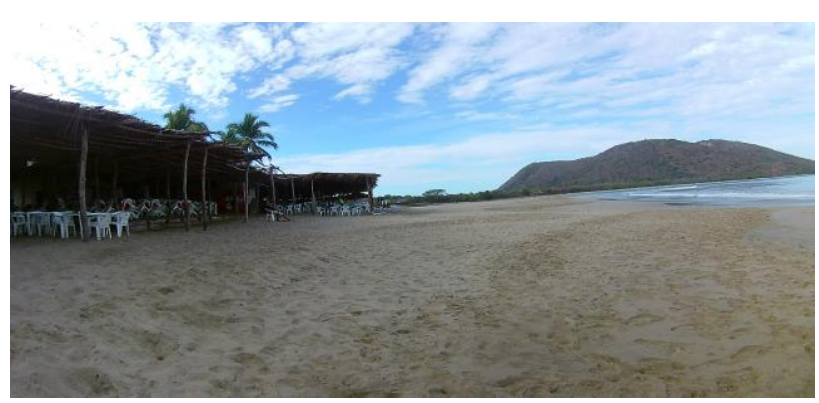

Figure 1 Potosí barrita

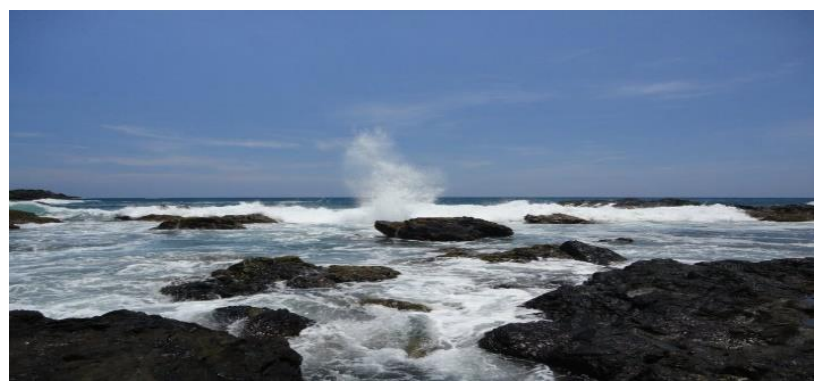

Figure 2 La barrita 


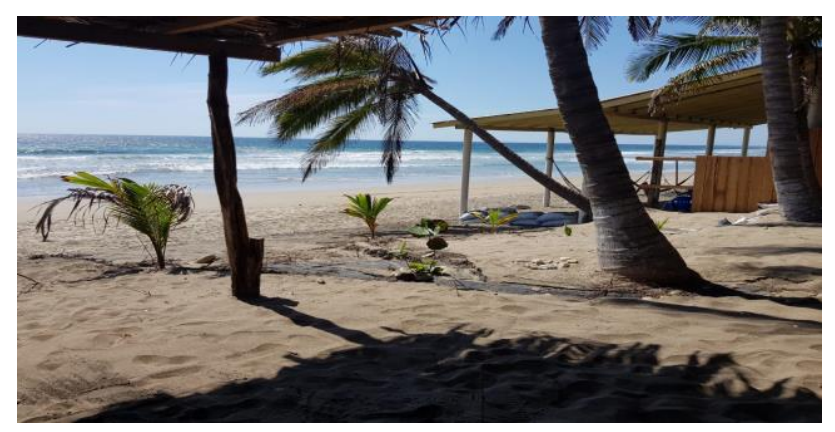

Figure 3 Discharge of soapy water

6. On the other hand, it is important to compare the differences in the link between service providers and the different levels of government.

\begin{tabular}{|c|c|c|c|c|c|}
\hline & Municipal & State & Federal & $\begin{array}{c}\text { State } \\
\text { Legislators }\end{array}$ & $\begin{array}{c}\text { Federal } \\
\text { Legislators }\end{array}$ \\
\hline $\begin{array}{l}\text { Barra de } \\
\text { Potosí }\end{array}$ & None & None & None & None & None \\
\hline $\begin{array}{l}\mathrm{La} \\
\text { Barrita }\end{array}$ & None & None & None & None & None \\
\hline
\end{tabular}

Table 6 Relationship with the different levels of government

There is no relationship between the service providers and the different levels of government, since they do not receive any support from any of the three levels, so due to their lack of capital, which does not allow them to hire advertising, or do improvements to their premises, as well as hiring technological services, to meet the needs of customers.

7. In that sense, another element to compare is the link with commercial and development banks, as well as with the Ministry of Economy, which service providers maintain.

\begin{tabular}{|l|l|l|l|}
\cline { 3 - 4 } \multicolumn{1}{c|}{} & \multicolumn{1}{c}{$\begin{array}{c}\text { Commercial } \\
\text { Bank }\end{array}$} & \multicolumn{1}{c|}{$\begin{array}{c}\text { Development } \\
\text { Bank }\end{array}$} & \multicolumn{1}{c|}{$\begin{array}{c}\text { Ministry of } \\
\text { Economy }\end{array}$} \\
\hline $\begin{array}{l}\text { Barra de } \\
\text { Potosí }\end{array}$ & None & None & None \\
\hline La Barrita & None & None & None \\
\hline
\end{tabular}

Table 7 Relationship with commercial, development and Ministry of Economy banking

There is no relationship between service providers and commercial, development and economic secretariat banking, due to the lack of financial planning, as well as poor administrative management, which in some cases only has a personal account, but not a business, which makes it difficult to access credit.

\section{Conclusions}

According to the data compared to both destinations, the Barra de Potosí have differences on the one hand, due to the proximity to the Municipality of Zihuatanejo de Azueta, and can access the technological services, in addition the tourism that arrives at this destination is both national and international, and within the tourist offer, La Barra de Potosí is offered, unlike La Barrita.

But both destinations have the same problem do not have the basic infrastructure of health services, which is increasingly noticeable, due to the smells that it emits when passing through the accesses.

Therefore it is vital that the government not only allows the growth of establishment and housing, but that it seeks problems to mitigate this problem, already in the XXI century, permits are still granted to build homes or establishments, without counting on the Sanitary drainage services, much less with a treatment plant, which will eventually affect the source of livelihood of the inhabitants of these destinations, as well as a recreation area for both locals and visitors.

It is also important to establish a better communication with the population, managing workshops, that allow them to access the different sources of financing, as well as in the management of waste, creating a culture of environmental protection, to preserve the source of livelihood, and recreation for visitors and locals.

\section{References}

Gómez, G. (1996) Planeación y organización de empresas (octava edición). México: Editorial Mc Graw Hill

Góngora, Norberto Hugo, Nóbile, Cecilia Inés, Soledad Reija, Lucía, ESTUDIO COMPARATIVO DE LA CULTURA ORGANIZACIONAL. Ciencias Administrativas [en línea] 2014, (JulioDiciembre): [Fecha de consulta: 02 de febrero de 2019] Disponible en: $<$ http://www.redalyc.org/articulo.oa?id=511 651380006> ISSN 
INEGI (2016) Conociendo Guerrero (Sexta Edición). México.

Piovani, J.I., Nora Krawczyk, N. (2017). Los Estudios Comparativos: algunas notas históricas, epistemológicas y metodológicas [en línea] 2017 (Julio-Septiembre): [Fecha de consulta 16 de agosto 2019] http://www.redalyc.org/jatsRepo/3172/3172530 08002/317253008002.pdf

Playas de Guerrero México. Playa La Barrita Guerrero México. (consultado el 02 de febrero del 2019) disponible en https://www.playasmexico.com.mx/playa-labarrita-1307.html

Playas de Guerrero México. Playa Barra de Potosí Guerrero México. (consultado el 02 de febrero del 2019) disponible en https://www.playasmexico.com.mx/barra-depotosi-514.html

Sartoria, G. (1984) La política, lógica y método en las ciencias sociales. México. Fondo de Cultura Económico. 